\title{
Local Wisdom Character Education Based on the Life Philosophy of R.M.P. Sosrokartono
}

\author{
Edris Zamroni ${ }^{1}$, Ristiyani ${ }^{2}$, Himmatul Ulya ${ }^{3}$, Erik Aditia Ismaya ${ }^{4}$, M. Noor Ahsin ${ }^{5}$ \\ UniversitasMuria Kudus, Kudus, Indonesia ${ }^{1,2,3,4,5}$ \\ \{edris.zamroni@umk.ac.id $\left.{ }^{1}\right\}$
}

\begin{abstract}
This article aims to explore the noble teachings of RMP Sosrokartono that are relevant to be integrated with the character education program run by the government. The method used is Gandamedian hermeneutics by examining ancient manuscripts belonging to R.M.P.Sosrokartono and artifacts that can still be traced so that the important points of authentic teachings of R.M.P.Sosrokartono in living his life are found. After that, the teachings that are relevant to the character education program are formulated. The results revealed five main teachings that are highly relevant to the main characters of character education that includes concern socially, religious, peace-loving, friendly, communicative, hardworking, independent, and tolerant.
\end{abstract}

Keywords: RMP Sosrokartono, Character Education, Teachings

\section{Introduction}

Government policy in the development of Indonesian education leads to reaffirming the characters and identity of the nation to become a strong nation by maintaining local wisdom while keeping up with the current development. Local wisdom character education will encourage students to carry out conservation to the cultures that possess noble values as the national property[1]. Character education is the answer to the globalization of information that brings a flow of information which currently tends to erode the original characters of the Indonesian people who are polite, friendly, responsible and noble [2].

Character education is considered a serious problem that must be carried out rather than a discourse. The importance of character education is due to important views which consider character education to be very closely related to psychological products in the form of expressions of love and affection, self-discipline and personality integrity[3]. Eventually, there is a growing awareness to maintain the educational values which include ethics, prosocial behaviors and the need to strengthen the focus of achieving academic success [4].

Indonesian local wisdom character education is one of the answers to the challenges of the disruption of noble cultural values that are currently experienced by this nation. Local wisdom character education can be developed through the internalization of cultural values derived from cultural products, social norms, central figures the teachings and exemplars of who are respected, and other customs and noble values that are believed to be true by the society [5]. There is a need to do an in-depth study to find values comprehensively to be integrated into the education system until the learning process in the classroom. In the US, the issue of character education has become a hot issue debated mainly with regard to who is 
responsible for moral education, democratic values, and life principles, and eventually, everyone agrees that teachers have an important role in it[6]. In the end, at the level of education, teachers must be convinced that every prospective teacher has the faith and confidence to be the frontline figure of character education for students.

R.M.P.Sosrokartono is a national hero known as the spiritual teacher of the first president of Indonesia. As a spiritual teacher, he was considered to have the wisdom, exemplary and life insights the thoughts of whom need to be explored deeper to be adopted in the development of the education system. Sosrokartono is a figure known to have the integrity between his words and his deeds, willing to be beneficial to the surrounding and sincerely selfless[7]. The most important teachings of Sosrokartono are controlling oneself by holding on to conscience, having social awareness, and promoting common interests, happiness and welfare [8]. Unfortunately, to date, his philosophy of life and teachings are only limited to discourse and have not been formulated in a technical form that can be operationalized for the implementation of education and learning in the field.

This article will review Sosrokartono's life views that are relevant to be developed and adopted in the systemic education atmosphere, and can be implemented. The hope is to find the operational formulations on how to restore the characters and personalities of the nation based on onSosrokartono's views and philosophy of life. Finally, the education expected to be able to restore the characters and personalities of the nation can be achieved.

\section{Method}

This research is a qualitative study using the hermeneutic method. This research interpreted the manuscripts that contained Sosrokartono's important thoughts about life. One manuscript was personally written bySosrokartono while the others were the writings of others who summarized Sosrokartono's thoughts and outlook on life, especially his communication experience as the spiritual teacher for Soekarno. The understanding of the text is then connected with the reality of contemporary society that synergy occurs seven though there is a disconnection between the texts and the author in terms of the subject.

The manuscripts interpreted in the books entitled Ilmu Kantong Bolongand Ilmu Sunjiby Sosrokartono were responded academically by R. Mohammad Ali[9]. The texts were then compared with other texts written by different authors to obtain the same views and orSosrokartono's authentic mindset as well as the reality of living conditions in society. The results were interpreted to obtain the values suitable for character strengthening and the implication in character education. Apart from the text, the interpretation of Sosrokartono's letters was also explored [10].

\section{Result and discussion}

\subsection{Result}

The results of manuscript investigation obtained letters that were sent as a counsel to President Sukarno because of Sosrokartonowas a spiritual teacher the counsels of whom were awaited. One screenshot of the obtained letters displayed in Figure 1. 


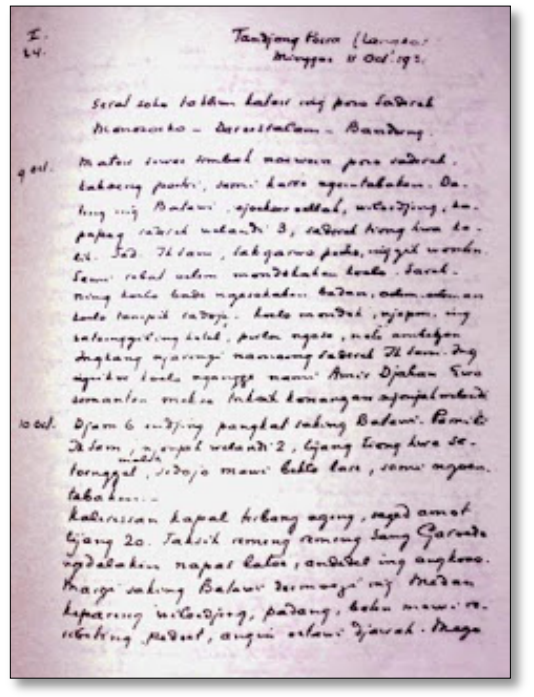

Figure 1. Sosrokartono's letter to President Soekarno [10]

The study of manuscripts in figure 1 and the exploration of the other manuscripts resulted in important outlines and redline from the live view and life philosophy presented in table 1. Table 1 does not take all the essence of the philosophy of life, but only the one considered still relevant to the implementation of character education in Indonesia.

Table 1. The analysis ofSosrokartono's life philosophy and its implications for character education

\begin{tabular}{|c|c|c|c|}
\hline No. & Life Doctrine/Philosophy & Meaning in Indonesian & $\begin{array}{c}\text { Value of } \\
\text { Character } \\
\text { Education } \\
\end{array}$ \\
\hline 1 & $\begin{array}{l}\text { Kanthong Bolong } \\
\text { "Nulung pepadhane, ora } \\
\text { nganggo mikir wayah, } \\
\text { wadhuk, kanthong. Yen } \\
\text { ana isi lumuntur marang } \\
\text { sesami" }\end{array}$ & $\begin{array}{l}\text { Perforated Bag. "Helping } \\
\text { others do not need to consider } \\
\text { our time, stomach, and pocket. } \\
\text { If it is available, let it go for } \\
\text { others" }\end{array}$ & social concern \\
\hline 2 & $\begin{array}{l}\text { Jaka Pring "Pring padha } \\
\text { pring. Weruh padha } \\
\text { weruh. Eling tanpa } \\
\text { nyanding" }\end{array}$ & $\begin{array}{l}\text { Bachelor Bamboo. "One } \\
\text { bamboo with } \\
\text { others.Knowing each other. } \\
\text { Remembering } \\
\begin{array}{l}\text { approaching." } \\
\text { without }\end{array}\end{array}$ & $\begin{array}{l}\text { Hardworking, } \\
\text { Honest and peace- } \\
\text { loving }\end{array}$ \\
\hline 3 & $\begin{array}{l}\text { Murid lan Guru Pribadi, } \\
\text { "Murid, gurune pribadi. } \\
\text { Guru, muride pribadi. } \\
\text { Pamulangane, sengsarane } \\
\text { sesami. Ganjarane, ayu }\end{array}$ & $\begin{array}{l}\text { Student and Private Teacher. } \\
\text { "A student is the teacher for } \\
\text { himself. A teacher is the } \\
\text { student of himself. The } \\
\text { learning place is the suffering }\end{array}$ & $\begin{array}{l}\text { Independent } \\
\text { Respectful } \\
\text { Achievement }\end{array}$ \\
\hline
\end{tabular}




\begin{tabular}{|c|c|c|c|}
\hline No. & Life Doctrine/Philosophy & Meaning in Indonesian & $\begin{array}{l}\text { Value of } \\
\text { Character } \\
\text { Education } \\
\end{array}$ \\
\hline & $\begin{array}{l}\text { lan } \\
\text { arume sesami. }\end{array}$ & $\begin{array}{l}\text { of others. The result is the } \\
\text { beauty and fragrance of } \\
\text { others. " }\end{array}$ & \\
\hline 4 & $\begin{array}{l}\text { Sugih tanpa Bandha, } \\
\text { "Sugih tanpa bandha. } \\
\text { Digdaya tanpa adji. } \\
\text { Nglurug tanpa bala. } \\
\text { Menang tanpa ngasorake" }\end{array}$ & $\begin{array}{l}\text { Wealthy without Assets, } \\
\text { "Being wealthy without assets, } \\
\text { being strong without } \\
\text { talismans, coming to enemies } \\
\text { without companions, winning } \\
\text { without humiliating." }\end{array}$ & $\begin{array}{l}\text { Friendly, } \\
\text { communicative and } \\
\text { peace loving }\end{array}$ \\
\hline 5 & $\begin{array}{l}\text { Trima mawi Pasrah, } \\
\text { "Trimah mawi pasrah. } \\
\text { Suwung pamrih, tebih } \\
\text { ajrih. Langgeng tan ana } \\
\text { susah, tan ana seneng. } \\
\text { Anteng antheng sugeng } \\
\text { jeneng" }\end{array}$ & $\begin{array}{l}\text { Sincere Acceptance. } \\
\text { "Acceptingsincerely, } \\
\text { selflessly, fearlessly. Being } \\
\text { eternal without feeling sad or } \\
\text { glad. Calmly focused while } \\
\text { reciting His names" }\end{array}$ & $\begin{array}{l}\text { Religious, } \\
\text { Hardworking }\end{array}$ \\
\hline
\end{tabular}

Table 1 shows that every life view and or life philosophy has noble values that are very relevant to the 18 character values currently optimized to be achieved through the character education system. Local wisdom character education is important to redevelop. Japan can be taken as an example since it clearly distinguishes education from the western approach and applies original education that is in accordance with Japanese culture[11]. It is never too late to keep improving the characters of the nation which begins to be eroded by the flow of globalization to become better through truly Indonesian character education.

Referring to table 1, the important values to teach are;(1) Perforated Bag (KanthongBolong) refers to the most prominent character of this teaching, which is social concern that suggests helping others without being self-sufficient first because help is not always related to the provision of materials. Making students used to help others even with small things is important to make them used to concern for the difficulties faced by their social environment. (2) BachelorBamboo(Jaka Pring) refers to the character of jaka or bachelors who are taught to connote a young spirit that is still passionate about working on various things and sometimes having to cross each other because of their idealism. The teachings further advocate to prioritize the common benefit and to maintain harmony even though they are not physically close. The spirit of hard work and harmony is very important to be taught and accustomed from an early age at the lowest level of education.(3)Student and Private Teacher (Murid lan Guru Pribadi)teaches that although one's position is as a student, at least he should be able to be a guide and a teacher for himself. The same thing applies for a teacher who, despite being a teacher, must also become a student for himself to continue to learn and develop through the dynamics of life in order to find the beauty, happiness, and kindness with others. This statement encourages us to become an independent individual who must continue to learn and have curiosity in order to develop and gain new insights, knowledge, and science from life experiences. (4)Wealthy without Assets (Sugihtanpa Bandha) refers to the social status, scientific position, and caste in the society that often limit our relationship with others. Students must be taught to have humility, friendliness, communicativeness, peace proposition, and respect for others, even to people who are hostile to them and they hate. Students must 
also be taught not to ask others to hate the people they hate even if their mistakes are difficult to forgive. And (5) Sincere Acceptance (Trimamawipasrah) teaches the importance of sincerity in accepting various life events no matter how unpleasant they are for him with the awareness that as a God's creature, he must sincerely accept the provisions of God while still trying to get a better life and being responsible for himself, the environment and to God.

\subsection{Discussion}

In 2045, Indonesia will have a demographic bonus that the potential and productive generations will become the majority of the population. Education is a central point of excellence for preparing human resources with extraordinary characters [12]. For this reason, the 2013 curriculum, which facilitates intellectual and academic development of human resources while maintaining the noble character possessed by the Indonesian nation, was developed [13]. This movement had actually been carried out by Turkey as well from 2004 to 2013 where access to education continued to be brought closer to the society in order to improve the quality of human resources and improve living welfare through professional wage provision [14]. Eventually, value and character-based education will encourage increased competence, ethics, prosocial behavior and academic focus strengthening for achieving students' success[4].

Character embedment is not an instant activity the result of which can be seen in a short time. Local wisdom character education can be the answer to the challenges in question which can begin with the culture enculturation process for both local wisdom and local knowledge which are believed to be true[15]. Even in theUnited States, the education of prospective teachers has been directed at preparing them to have personality or character education ability, and education and teaching ability in general[6]. Over the past 15 years, the United Kingdom has focused its educational investment interest in strengthening character education until reaching general government policies [16].

Local wisdom includes customs and other cultural products including languages that are consciously admitted and used together by certain groups of people and tend to be the identifier from other groups of society. This identifier sometimes becomes a link between cultural acculturations even if it is only in the form of language the study of which in Japan showed the existence of language acquisition issues by Latin American students studying in Public Schools in Japan to achieve their academic goals[17]. Synergizing local wisdom values for character education is an important agenda in educational programs where opportunities must be opened to continue to explore the noble values of local culture that are close to the society so that later more massive dissemination can be performed both at national and international levels[1], [5], [18], [19]. Research in Texas showed that character education was strongly encouraged to inspire students to make positive changes in their lives and treat each other with kindness and compassion[20]. The focus of character education, in addition to the 18 character values that have been formulated by the ministries of education and culture, also refers to the efforts to achieve the 2045 golden generation with the focus on education: 1 . Strengthening academic skills with logic and honesty; 2 cultivating Nationalism; 3. Cultivating concern, tolerance, and respect; 4. Cultivating democratic values; and 5. Upholding the law [12].

The important teachings of Sosrokartono provide guidance on the education side and life learning to shape students' personality. The latest research found a significant relationship between the success of character education through the synergy of the values and implementation of all school components with the formation of personality and improvement 
of student achievement [21]. Another study also identified that life comfort is also influenced by perceptions on the situation and the contents of the environment where one lives which is an important part of the environment-concern character for Indonesian [22]. Sosrokartono taught social concern by using the diction Perforated Bag (Kanthong Bolong) meaning that when humans want to be beneficial to other humans, there is no need to wait until they have the wealth. This is what determines the perception to be comfortable because unconsciously humans will always be conditioned to want to do even the slightest good deeds.

\section{Conclusion}

The exploration results of this study found Sosrokartono's important teachings formulated in terms of Perforated Bag (KanthongBolong), BachelorBamboo (JakaPring), Student and Private Teacher (Murid lan Guru Pribadi), Wealthy without Assets (SugihtanpaBandha) and Sincere Acceptance (Trimamawipasrah). First, he emphasized the teaching of social concern to continue being beneficial to others without having to wait for having enough wealth, hardworking, honest, and peace-loving that must be performed in a straightaway like bamboo philosophy as well as mutual respect to preventing conflicts. Independence and respect for one's achievements are taught through the reflection that students must be able to become a teacher for themselves, and the vice versa, teachers, must be positioned as a student to continue learning about the life-changing dynamics. This point teaches independence and appreciation of for others' achievements. Friendly behavior is also taught through Wealthy without Assetsteaching where humans must continue trying to maintain peace. Finally, the last teaching emphasizes insincere acceptance for what is done and what is owned. These wise values need to be internalized through the adoption of learning methods as well as habituations in educational activities at school since primary education.

\section{References}

[1] N. F. Istiawati, "Pendidikan Karakter Berbasis Nilai-nilai Kearifan Lokal Adat Ammatoa dalam Menumbuhkan Karakter Konservasi," Cendekia, vol. 10, no. 1, pp. $1-18,2016$.

[2] T. Trianton, "Nilai Pendidikan Karakter Berbasis Kearifan Lokal dalam Film Indie Banyumas," Anim. Genet., vol. 39, no. 5, pp. 561-563, 2008.

[3] W. H. Jeynes, "A Meta-Analysis on the Relationship Between Character Education and Student Achievement and Behavioral Outcomes," Educ. Urban Soc., p. $1312451774768,2017$.

[4] M. W. Berkowitz, "What works in values education," Int. J. Educ. Res., vol. 50, no. 3, pp. $153-158,2011$.

[5] G. C. Kesuma, "Pendidikan Karakter Berbasis Kearifan Lokal Adat Sunda 'Nglaksa' Tarawangsa di Rancakalong Jawa Barat," Al-Tadzkiyyah J. Pendidik. Islam, vol. 7, no. 1, pp. 35-44, 2016.

[6] S. Waters and W. B. Russell, "Preservice Secondary Teachers' Sense of Efficacy in Teaching Character Education," J. Educ., vol. 194, no. 2, pp. 45-54, 2014.

[7] Mulyono, "Ajaran Moral Sosrokartono dari Perspektif Teori Etika Deontologisme," Humanika, vol. 20, no. 2, pp. 1-6, 2014.

[8] Mulyono, "Binner Ethical Ajaran Sosrokartono dalam Perspektif Hermeneutika," Humanika, vol. 19, no. 1, pp. 104-113, 2014. 
[9] R. M. Ali, Ilmu Kantong Kosong, Ilmu Kantong Bolong, Ilmu Sunji. Kudus: Menara, 1966.

[10] I. G. Hakim, Tafsir Surat-surat \& Mutiara-mutiara Drs. R.M.P. Sosrokartono. Yogyakarta: Pustaka Kaona, 2008.

[11] I. Davies, M. Mizuyama, and G. H. Thompson, "Citizenship Education in Japan.," vol. 9, no. 3, p. 213, 2011.

[12] F. Rokhman, M. Hum, A. Syaifudin, and Yuliati, "Character Education for Golden Generation 2045 (National Character Building for Indonesian Golden Years)," Procedia - Soc. Behav. Sci., 2014.

[13] R. Fahmy, N. Bachtiar, R. Rahim, and M. Malik, "Measuring Student Perceptions to Personal Characters Building in Education: An Indonesian Case in Implementing New Curriculum in High School," Procedia - Soc. Behav. Sci., vol. 211, pp. 851-858, 2015.

[14] S. Polat, "The Expansion of Higher Education in Turkey: Access, Equality and Regional Returns to Education," Struct. Chang. Econ. Dyn., vol. 43, pp. 1-14, 2017.

[15] I. W. Rasna and D. K. Tantra, "Reconstruction of Local Wisdom for Character Education through the Indonesia Language Learning: An Ethno-pedagogical Methodology," Theory Pract. Lang. Stud., vol. 7, no. 12, pp. 1229-1235, 2017.

[16] K. Allen and A. Bull, "Following Policy: A Network Ethnography of the UK Character Education Policy Community," Sociol. Res. Online, vol. 23, no. 2, pp. 438458, 2018.

[17] G. Castro-Vázquez, "The educated citizen: Cultural and gender capital in the schooling of Latin American children in Japan," J. Res. Int. Educ., vol. 10, no. 3, pp. 244-260, 2011.

[18] L. L. N. Mufidah, "Pemikiran Gusdur tentang Pendidikan Karakter Kearifan Lokal," Al-Tahrir, vol. 15, no. 1, pp. 91-110, 2015.

[19] M. Priyatna, "Pendidikan Karakter Berbasis Kearifan Lokal," J. Edukasi Islam. J. Pendidik. Islam, vol. 5, no. 1, pp. 1311-1336, 2016.

[20] B. Hollingshead, "The concerns-based adoption model: A framework for examining implementation of a character education program," NASSP Bull., vol. 93, no. 3, pp. 166-183, 2009.

[21] G. Skaggs and N. Bodenhorn, "Relationships Between Character Education, Implementing Student Behavior, and Student Achievement," J. Adv. Acad., vol. 18, no. 1, pp. 82-114, 2006.

[22] M. M. Pane and R. Patriana, "The Significance of Environmental Contents in Character Education for Quality of Life," Procedia - Soc. Behav. Sci., vol. 222, pp. 244-252, 2016. 